\title{
Higher Education Reform in Argentina
}

\section{By Carlos Pujadas}

Carlos Pujados is Academic Secretory, Universidad Austrol, Juan de Garay 125, (1062) Buenos Aires, Argentina. Fax: 54-1-361-1329; e mail:Postmaster@uaurec.edu.ar.

$A \mathrm{fte}_{\mathrm{r}}$ months of long and bard negotiations the Minis1 try of Education finally achieved its purpose, and the Congress passed the new general Law on Higher Education. Presently the students associations and the administrations of the national universities belong to the Radical Party, the leading opposition party. This political situation strengthened resistance to a law restricting university autonomy and opening the door to the payment of fees in public universities.

The main change introduced by the law is the demand for institutional assessment and accreditation, through a committee establishedby the law, or through private agencies to be recognized by the national government. This means that the public universities will lose some of their autonomy, once they have submitted, for the first time, to greater control by government supervision.

On the other band, privateuniversitiesthat do not have the benefit of national grants will be subject to a strict evaluation process inherited from the Argentine university system: academic degrees also serve to qualify graduates for the professions, and must therefore be controlled by the government.

This detailed law regulates, through its 85 articles, the whole system of higher education -33 national universities, 5 provincial universities, and 39 private universities. The system is expanding through the creation of new universities.

According to the 1994census, 615,000 students attend national universities. The dropout rate is very high: only 19 percent of those who enroll finish their studies, which adds to the low efficiency of the system.

The total budget of the government-supported universities amounts to $\$ 1.5$ billion. And the cost for each graduate is $\$ 35,000$. Only 2 percent of the student population receives some kind of scholarship.

Fifty-four percent of the students alsowork, although most of them have pan-time jobs, which serves to lengthen the period of their studies. It takes about 10 years for a high percentage of students to graduate.

The National University of Buenos Aires is the leading institution, with 169,000 students, 6,810 professors ( 11.5 percent of them are full-time), and 15,342 teaching support staff. It is an extreme example of this Latin American model of higher education, one characterized by free ac- cess obtained with the simple completion of secondary school, dominated by professional studies, scarce research, and a demoralized professoriate, composed largely of part-
time professors.

The great expansion in university enrollments that started in 1970 was not a process accompained by rational decisions to ensure educational quality. The Argentine university, which some decades ago held a position of prestige in Latin America, with two Nobel Prizes in Medicine and Chemistry, is now clearly in decline.

On the other band, a number of private universities have been established, since 1955 . There are 75,000 students enrolled in these 39 universities, 17 of them founded in the last five years, during the present government of President Carlos Menem. Private universitieshave survived on revenues provided by student fees (an average of $\$ 3,500$ annually per student) and have not attempted to have fulltime professors or to perform research, as do public universities. Only a few of the new private universities have hied to follow the American research university model.

The first two chapters of the new law are short and define the system of higher education. This system is comprised of all the institutions of postsecondary education national, provincial, and municipal, both public and private. It seems appropriate that both public and private institutions are included under the same law. Moreover, pointing out their common objectives may contribute to overcoming the historical mutual distrust and resentment between these two subsystems.

The Law sets the guidelines for the development of a wide sector of nonuniversity tertiary education, mainly for teacher training schools and institutions of professional and artistic education.

This nonuniversity sector is undergoing development in Argentina as well as in other countries, and it involves over 25 percent of postsecondary education.

The fourth chapter of the law is the longest one; it is dedicated to university higher education. It signals the promotion of diversification, which seems promising. From now on, universities are to be differentiated from universitaryinstitutes, which arc those that limit their academic offerings to a sole disciplinary area.

This chapter of the law also describes the scope of institutional autonomy, the ranking of titles and grades, and the rules of evaluation and accreditation.

All the universities must undergo an external evaluation every six years, and recommendations for institutional improvement will be made public. 
The law also creates a National Committee of Evaluation and Accreditation, made up by representatives of the academiccommunity and the Congress. As we have already stated, the law allows for the use of private agenciesto perform this function. Bearing in mind the institutional instability experienced in Argentina and the mistrust of a possible arbitrary exercise of governmental power, private universities have been quick to support the creation of this private agency.

Public opinion has expressed approval for the introduction of these mechanisms to ensure quality. The negative side involves the interference of the government in academic matters because of the linking of the academic degreewith the professional habilitation. It should be noted, in order to clarify this point, that there are no general education degrees in Argentina (such as the Bachelor's degree) and that the majority of the academic degrees coincidewith professional degrees.

Concerning the governance of public universities, the law states that the governing boards and committees may be comprised of professors, students, alumni, and administrative persbnnel. The faculty participation has been set at SO percent-in an attempt to restore some of their former power.

Another welcome step is that each national university may set its own salaries. Up to now, salarieswere set by an uniform scale, which gave rise to all kinds of inconsistencies.

The law does, however, also create more national and regional offices, which may increase the bureaucracyof the system.

The authors of the new law on higher education were confronted by structural failures in addition to a range of problems affectinguniversities equal to those found in any other counuy. In the first issue of International Higher Education, it was amazing to the author to find that similar problems were reported in Japan, India, Chile, and Korea. It is a practical way of showing the globalization of our world.

\section{News of the Center and the Higher Education Program at BC}

$\mathrm{T}$

$e$ Review of Higher Education, a major scholarly journal in the field of higher education and the official publication of the Association for the Study of Higher Education, will move its editorial offices to Boston College in 1996. The Review is a quarterly journal that features the latest research on higher education, as well as reflections on the field of higher education studies. The Review welcomes the submission of articles on all aspects of higher education. Information about submitting articles as well as subscription'information can be obtained from the editor, Philip G. Altbach, Campion Hall, Boston College, Cbesmut Hill, MA 02167.

The new Administrative Fellows Initiative in the Higher Education Program is in the midst of its first year of operation. Fourteen fellows work in a variety of Boston College administrative and other departments. They pursue full-time academic work as well as holding an assistantship. Aspecial seminar is provided for the fellows. Fellowship holders receive a stipend and a tuition scholarship. Information on the initiative is available from Prof. Ted Youn, coordinator.

$$
* * *
$$

Applicants are welcome for the masters and doctoral programs in Higher Eduation at Boston College for study in the 1996-97 academic year. The Boston College School of Education was recently ranked no. 16 in the United States by $U . S$. News and World Report. The Higher Education Program, active for more than 30 years, is well regarded nationally. Special focion student affairs, the organization of higher education, and comparative and international higher education are part of the program. Application materials can be obtained from the Graduate Admissions Office, School of Education, Campion Hall, Boston College, Chestnut Hill, MA 02167. Information can be obtamed from Prof. Karen Arnold, Coodmator, Program in Higher Education. Tel: (617) 552-2649, Fax: (617) 5528422, or e-mail: Arnold@Hermes.Bc.Edu. 